\title{
EVALUATION OF THE DIFFERENCES IN KINDERGARTEN'S CLASSROOM DESIGNS ON STUDENT PROJECTS
}

\author{
Hamide TEMEL \\ Maltepe Üniversitesi, Türkiye \\ hamidebilgen@maltepe.edu.tr \\ https://orcid.org/0000-0002-2049-7160

\begin{tabular}{|c|l}
\hline \multirow{4}{*}{$t \boldsymbol{t} f$} & $\begin{array}{l}\text { Temel, H. (2021). ANAOKULLARI SINIF TASARIMLARINDAKİ FARKLILIKLARININ } \\
\text { ÖGRENCI PROJELERI ÜZERINDEN DEĞERLENDIRILMESİ. The Turkish Online } \\
\text { Journal of Design Art and Communication, 11 (4), 1285-1296. }\end{array}$
\end{tabular}

\begin{abstract}
It is known that kindergartens play a major role in providing the most basic education before children enter a more formal education program such as primary and secondary schools. The number of preschool education institutions has increased with the effect of the increase in the working female population and the change in working conditions. In these institutions, the main purpose of which is to provide the children with the necessary care and compassion in the absence of the mother, the child spends most of his time. Within the scope of the study, kindergartens serving the 3-6 age group and affecting the mental development of this age group to a great extent and having a special place in all education processes were discussed. Considering the past studies, it has been seen that the kindergarten design is examined from three main aspects, including architectural elements, geographical aspects and technical aspects. However, this article covers the classroom spaces, where the most time is spent in kindergarten. The effect of the interior on the child's psychology and the level of acceptance of education is an undeniable element. Based on this, Kindergarten design was given to Interior Architecture 4th grade students as the subject of Design Studio. In the studio, where the interior design of an existing private kindergarten is made, the physical and psychological characteristics of the child, the child, the space, the effects of the space on the child, the psychological effects of the colors, textures and forms that can be used, etc. The subject was focused on, the current situation was determined by visiting the field, a requirement program was created and analyzes were made. In this study, only the differences and common aspects of the classroom spaces were discussed in the group of 5 people, each of which produced original projects.
\end{abstract}

Keywords: Child, Children's Spaces, Kindergartens, Student Project.

\section{ANAOKULLARI SINIF TASARIMLARINDAKİ FARKLILIKLARININ ÖĞRENCİ PROJELERİ ÜZERINDEN DEĞERLENDİRILMESİ}

\section{$\ddot{O Z Z}$}

Anaokullarının çocukların ilk ve orta okullar gibi daha resmi bir eğitim programına girmeden önce en temel eğitimi sağlamada büyük rol oynadığı bilinmektedir. Çalışan kadın nüfusunun artması ve çalışma koşullarındaki değişimin etkisi ile okul öncesi eğitim kurumlarının sayısı artmıştır. Ana amacı annenin yokluğunda çocuklara gerekli bakım ve şefkati vermek olan bu kurumlarda çocuk zamanının büyük çoğunluğunu geçirmektedir. Çalışma kapsamında 3-6 yaş grubuna hizmet eden ve bu yaş grubunun 
mental gelişimini büyük oranda etkileyen ve tüm eğitim süreçleri içerisinde özel bir yere sahip olan anaokulları konu edilmiştir. Geçmiş araştırmalara bakıldığında anaokulu tasarımını mimari unsurları, coğrafi hususları ve teknik hususları içeren üç ana yönden incelendiği görülmüştür. Ancak bu makale anaokulunda en çok vakit geçirilen yer olan sınıf mekanlarını kapsamaktadır. İç mekânın çocuğun psikolojisine ve eğitimi kabul etme seviyesine etkisi yadsınamaz bir unsurdur. Buradan yola çıkarak İç Mimarlık 4. sınıf öğrencilerine Tasarım Stüdyosu konusu olarak Anaokulu tasarımı verilmiştir. Mevcutta bulunan özel bir anaokulunun iç mekân tasarımı yapılan stüdyoda, çocuk, çocuğun fiziksel ve psikolojik özellikleri, mekân, mekânın çocuğun üzerindeki etkileri, kullanılabilecek renk, doku ve formların psikolojik etkileri vb. konular üzerinde durulmuş, alana ziyaret gerçekleştirilerek mevcuttaki durum tespit edilmiş, ihtiyaç programı oluşturulmuş ve analizler çıkartılmıştır. Her birinin özgün projeler ürettiği 5 kişilik grup içerinde bu çalışmada sadece sınıf mekanlarındaki farklılıklar ve ortak yönler ele alınmıştır.

\section{Anahtar Kelimeler: Anaokulu, Çocuk, Çocuk Mekanları, Öğrenci Projeleri.}

\section{INTRODUCTION}

Preschool education is defined as the development and education process that covers the years from the day the child is born to the day, he starts basic education and plays an important role in the later lives of children. It helps the child to complete his physical, psychomotor, social-emotional, mental and language development to a great extent and to shape his personality with the education given in families and institutions (Deretarla Gül, 2008).

According to the 6th article of the Pre-School Education Institutions Regulation, kindergartens; it exists to enable children to develop body, mind and emotion and to acquire good habits, to help children acquire their imagination, creative and critical thinking skills, communication and expressing their emotions (URL-1).

Education provided to children in early childhood is critical to underpinning lifelong character formation. Turkey Statistics Institute (TSI), 41.8\% of children aged 3-5 years in our country, according to the 2019 uses pre-school institutions. It is an undeniable fact that this number will grow in the future with the increase in the number of working women (URL-2). This changing demographic environment shows how important educational institutions will play alongside the mother factor in the growth of children.

Educational structures were the first social organizations with children. The main objectives of educational structures, which are institutions that provide education, produce and transfer culture, are to ensure the adaptation of the individual to the society. School buildings, on the other hand, are microcosmic models that best reflect the values and world views of the society and understanding of education. Today, as in the past, it can be easily reached an opinion about the ideals of that society and its expectations from the future by looking at the understanding of school in the societies (Gür \& Zorlu, 2002).

Preschools, defined as gardens for children, initially implied the idea that children are blooming plants, derived from the concept of school as a metaphorical garden. The first kindergarten to form this term was founded by Friedrich Wilhelm August Fröebel (1782-1852) in the small Principality of Schwarzenburg-Rudolstadt in Germany. Froebel is considered to be the most influential person behind the development of schools for young children. Later, fans affected by Froebel migrated to other countries, bringing this new kindergarten movement with them (Mohidin et al., 2015).

It is known that pre-school education in Turkey goes back to the period of Sultan Mehmet the Conqueror (15th century). In this period, there were schools that could be considered as pre-school education institutions. However, according to Akyüz (1996), official kindergartens were opened and became widespread after the Balkan Wars (20th century). II. Sat1 Bey, one of the educators of the constitutional period, opened a private kindergarten in Beyazit, Istanbul. This kindergarten has become the school of

Research Article - This article was checked by iThenticate 
wealthy families in Istanbul in a short time. At the school, each child was taken care of individually by giving awards in the light of the views of famous educators such as Pestalozzi, Froebel, and Montessori, creating an educational environment free from all kinds of financial punishment. When the Republic was established, there were around 80 kindergartens throughout the country (Deretarla Gül, 2008).

\section{CHILDREN AND KINDERGARTEN}

Although there are various definitions, generally all individuals under the age of 18 are defined as children. The development and growth process of a child, who has similar physical and mental characteristics at certain periods, cannot be separated from each other by certain limits. These features can be considered separately as infancy (0-36 months), first childhood (preschool age, 3-6 years), last childhood (school age, 6-11 years) until adolescence. This article will focus on kindergartens designed for children aged 3-6, called the first childhood period. Children in this age group share the same building in educational institutions but receive education in separate classes. There are differences in education for each age group whose physical and perceptual / cognitive characteristics differ. While the age group of 3 gets a game-oriented education, the age group 6 prepares for primary education. In this case, differences can be seen from the furniture in the classroom to the colors.

Preschool education structures, where children first socialize with their many peers, make a great contribution to the personal development of children as a space. Interacting with the space, the child makes positive and / or negative inferences from the surrounding colors, textures and even forms. For this reason, it is important to make functional and ergonomic analyzes by paying attention to these specified elements in children's spaces and to design spaces that can minimize their physical damage.

\section{Kindergarten Interior Design}

Children spent up to 7600 hours in kindergartens before starting first grade. Therefore, the design of these facilities should not be underestimated. The design and maintenance of a child's physical education environment should support high quality activities as well as allow an optimum use that promotes quality learning. It is extremely important to design an interior suitable for the developmental levels of the preschool age group and to support their physical and cognitive levels. For this age group that learns with play, it is necessary to provide the activity area density in the spaces.

In a study by Şahin and Türkün Dostoğlu (2012), it was observed that $66 \%$ of the girl participants preferred the classroom, $17 \%$ the garden and $17 \%$ the playground as the favorite place of kindergarten children to play games at school. While only $17 \%$ of the male participants preferred the classroom, $50 \%$ preferred the playground in the basement, $25 \%$ preferred the garden and $8 \%$ preferred the gym.

In places that are carefully designed for kindergarten education, children should be encouraged to have various experiences while spending time mainly playing games. Education in kindergarten should be comprehensive and yet tailored to the individual needs of the children. In this design process, the minimum spaces that should be in kindergartens should be determined and the most suitable design should be made for these spaces.

\section{Spaces in Kindergarten}

Kindergartens consist of entrances, corridors, classrooms, playgrounds, toilets, sleeping rooms, dining hall / kitchen, administrative department, teacher's rest room, infirmary. Within the scope of the article, classroom spaces will be emphasized, but since the students are asked to complete the interior design of the kindergarten, brief information is given about the other departments that are studied extensively.

\section{Entrance}

The first places that children and their parents encounter in the institution are the entrances. The first impression of this place where families will deliver their children throughout the day and children will spend all day away from their families is extremely important. Intimate and trust-building entrances should be designed to make parents say "This is the best place for my child". 
At the same time, it is important to have a width that does not negatively affect the passage of children and their families during the rush hours when entering and leaving the school, and even to have a separate door for children who use the service to ensure comfortable circulation.

\section{Classrooms / Activity Rooms / Learning Centers}

In the 2013 Preschool Education Program of the Ministry of National Education, it was emphasized that the classrooms were designed to meet the children's free play and education needs and that well-designed educational environments support children's effective learning and develop creative problem solving skills. There should be playgrounds (learning centers) in classrooms that are suitable for the physical characteristics of the child and that can meet the needs of free play. A detailed examination will be made through student studies on the features and design of classroom spaces as required by the subject.

\section{Playgrounds}

Kindergartens require large playgrounds where children can freely play and run. Indoor playgrounds are frequently used, especially if the garden cannot be used in bad weather conditions. At this point, having a wide opening and high ceiling is an important factor for the design to be effective.

\section{Pedagogue Room}

According to the 28th article of the Pre-School Education Institutions Regulation (URL 1), it is essential to have a psychologist in preschool institutions in order to solve the psychologically healthy development of children and the problems that may arise.

\section{Sleeping Rooms}

Kindergarten age children (especially 3-4 years old) may need to sleep in the middle of the day in order to regain the energy they lost during the day. Children who refuse to sleep (usually 5-6 age group) can rest by lying on their bed. In this case, there are rooms in the institution that are away from noise, sound insulation and even a sound system is installed for children to sleep comfortably.

\section{Dining hall}

Dining halls should be designed to serve all students in the same period of time in kindergartens, and where children can be trained in eating. The design of these spaces is extremely important, as the colors and forms to be used will have positive / negative effects on children's eating habits.

\section{EXAMINATION OF CLASSROOM SPACES ON STUDENT PROJECTS}

The fixed and moving components of the design work together to serve the various developmental needs of the child. In this framework, it is necessary to act in a way to reach the result in design thinking from concept to implementation. Fixed and mobile components in the space affect the emotional, physical, cognitive and social development of children (Picture 1). Any point that is skipped or made wrong will negatively affect this cycle. Fixed components in the interior are columns, beams, stairs, floors, doors, windows and walls; moving components can be furniture and sometimes walls. An interior designer has an active role in the design of all these components. Its color, texture, material, form, functionality and aesthetics emerge with its design.

Research Article - This article was checked by iThenticate 


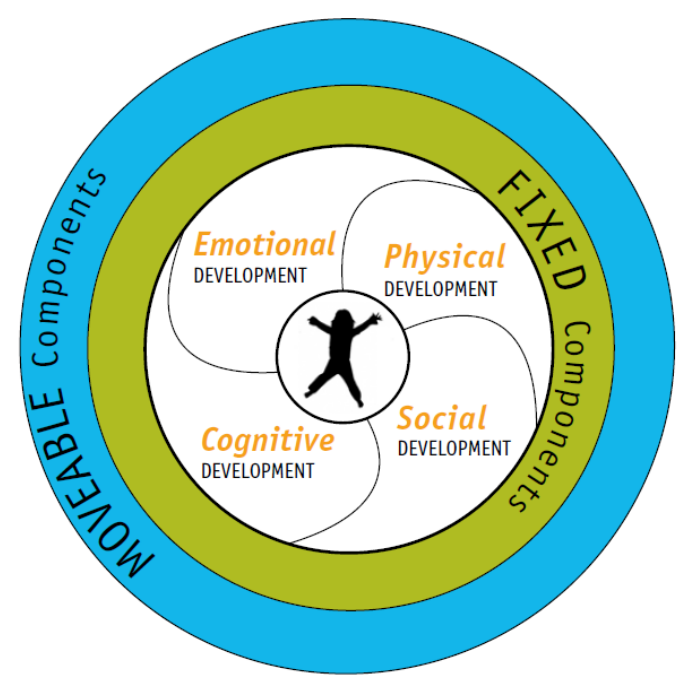

Picture 1. The effect of mobile and fixed components on the child's development

Source: Campbell (2013).

In order not to adversely affect the physical development of children in kindergarten classroom spaces, especially in mobile components, ergonomic furniture, fixed furniture and surfaces that can be climbed and crawled should be designed to support physical development.

Care should be taken to have furniture that can play group games to support social development, and all fixed and mobile components used in the space to be in appropriate color and form to support emotional and cognitive development.

In the light of all this information, Interior Architecture 4th grade students have developed a kindergarten design that will serve 3-6 age group within the scope of the Design Studio course. Without deviating from the general problem and concept, the designs were evaluated with a fluid working process and the result was reached.

The students were given a plan for an existing private kindergarten to be redesigned. The ground floor of this school, which belongs to a private institution located in Başıüyük District of Istanbul province, is $1241 \mathrm{~m}^{2}$, the first floor is $1103 \mathrm{~m}^{2}$ and the roof floor plan is $481 \mathrm{~m}^{2}$. However, the students were asked to solve only the ground floor plan within the scope of this project. While this structure with a large garden was being redesigned, various connections between the garden and the interior and the arrangement of new spaces in the garden were freed. Discussions were made on the necessity of children using the kindergarten to interact with the garden as much as possible, and solutions were produced.

\section{Student Work 1}

Starting off from the effects of colors on children, the student worked by integrating color and form throughout the term. He created various playgrounds by using elevation differences in the spaces and made a design that attracted the attention of children with different color tones in each space (Picture $2)$. 


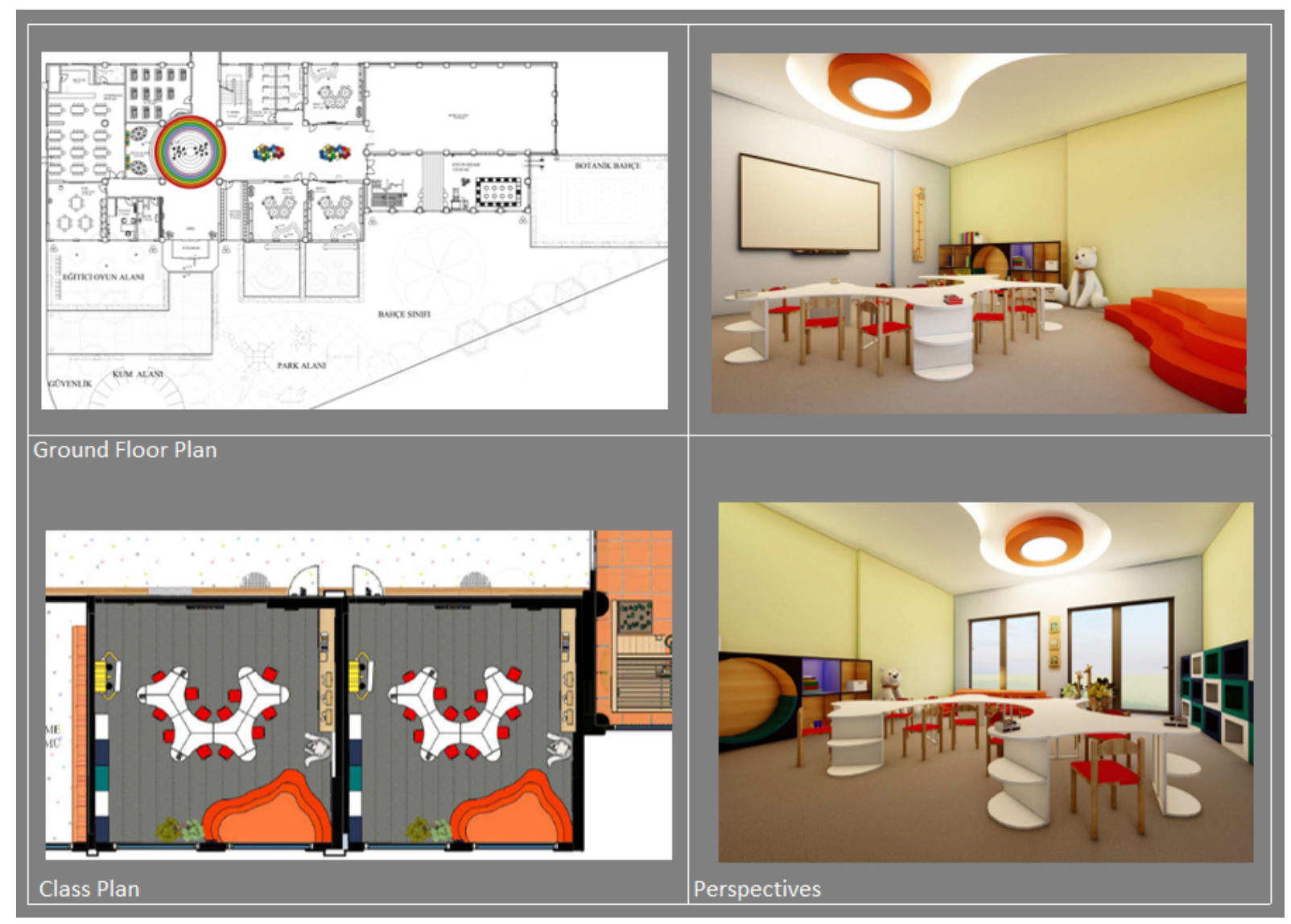

Picture 2. Student drawings and models

In this study, the student designed classrooms for 12 children. The main purpose in classroom designs is to make a place in the studio according to the activity. For this reason, a platform consisting of elevation differences was organized in the classroom where children can sit and talk as a group, and sit and listen while the teacher reads stories.

Children can develop their imaginations by looking at picture books, they enjoy reading with their friends and expanding their world. Based on this idea, a special area was created for children by making an integrated design with the bookcase section.

Tables are designed to be split for group activities or to combine the whole class to operate together.

Special open spaces were created for children by exiting from the front of the classroom facing the garden, in order to provide as wide a range of movement as possible both inside and outside.

In order to help children, socialize and be extroverted, shades of orange color were used predominantly in the classrooms. The traces of the organic form used on the tables were continued in the level difference used on the ceiling and floor. Antibacterial PVC coating was used on the floor and water-based paint was used on the walls.

\section{Student Work 2}

Based on the effects of the game on children, the student developed its design in order to design areas where children can play games in every place they are in or to provide easy access to the areas where they can play (Picture 3). 


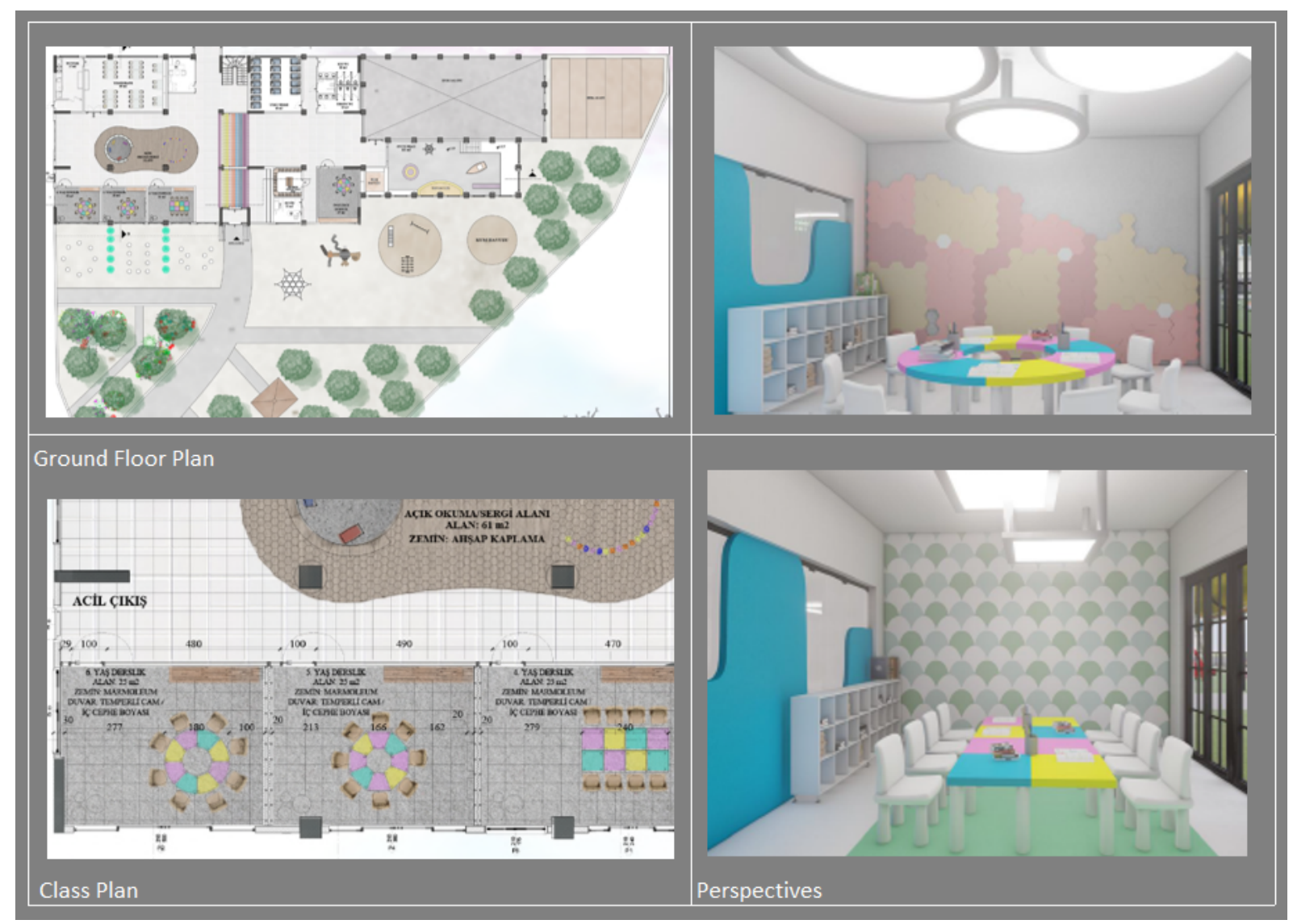

Picture 3. Student drawings and models

In this study, the student designed classes with 8 children. The main purpose of classroom design is to design transparent spaces where children will feel safe. For this reason, the surfaces of the classrooms facing the corridor are divided by transparent materials that do not distract children (Figure 9).8 tables were arranged in the classrooms where each child can sit individually but can be combined and allow them to do group work.

The units for children's personal belongings are designed as an open shelf system. In order for the children to provide as much movement as possible both inside and outside, an exit was made from the front of the classroom facing the garden and special open areas were created for children.

The classroom is generally designed using white tones to create a sense of safety in children, but different color tones are also used on furniture, wall surfaces and floors, as the excess of white color can cause unrest. Marmeloum and antibacterial carpet on the floor, tempered glass and water-based paint were used on the walls.

\section{Student Work 3}

Starting from the fact that geometric shapes are an effective factor in attracting the attention of children, the student used geometric forms on the surfaces and reinforcements starting from the entrance door of the kindergarten (Picture 4).

Research Article - This article was checked by iThenticate 


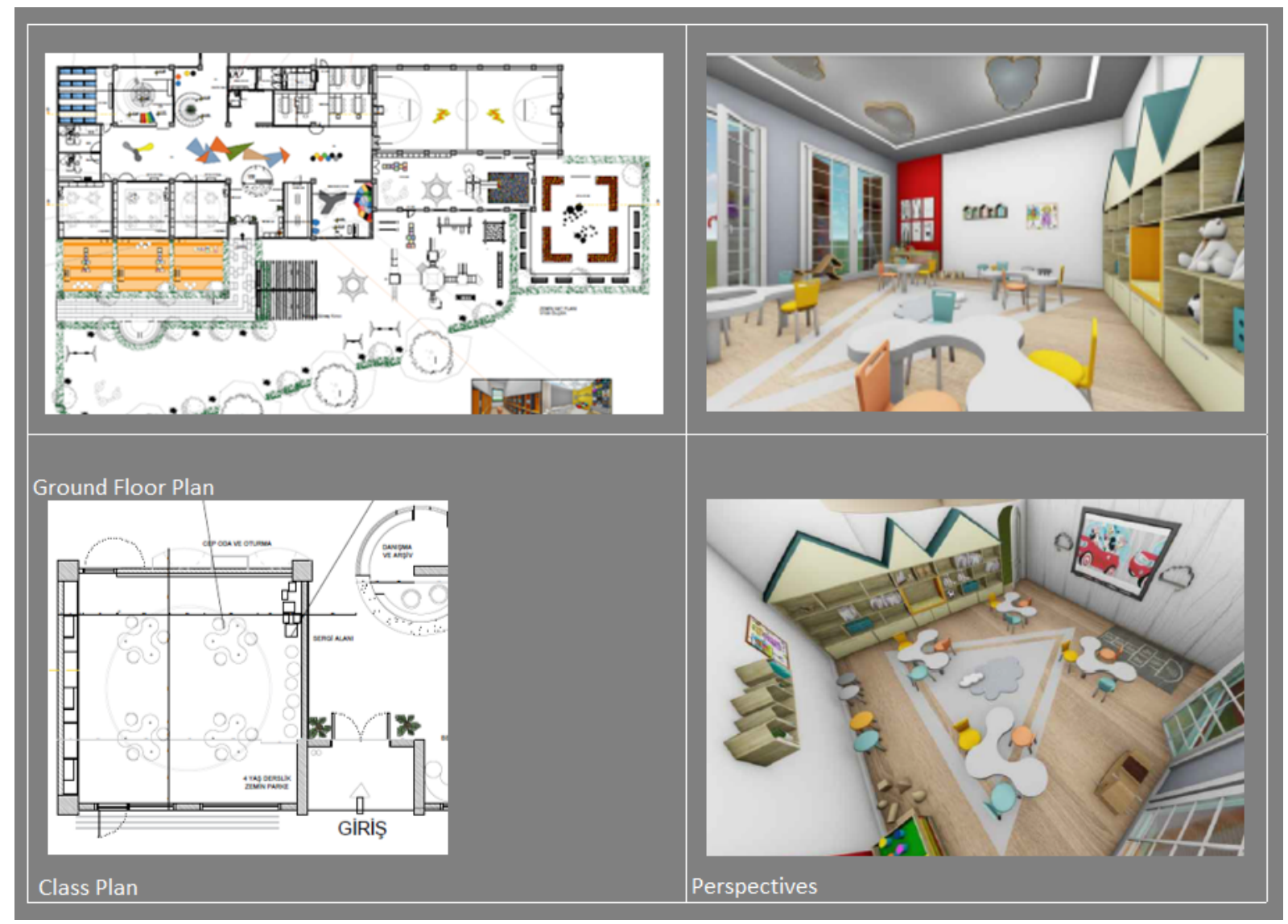

Picture 4. Student drawings and models

In this study, the student designed classes with 12 children. The main purpose of classroom design was to enable the surfaces in the space to be used as a game tool as possible. In order to allow children to move freely and discover their abilities, wide spaces were left in the space and wooden puzzles were placed on the wall surfaces in which children could create different forms with the pull-and-paste method (the student could not make a visual expression in three dimensions he made). Geometric forms continue on the ground. Circle, triangle and square form were used in the three designed classrooms. 4 desks were used in the classrooms for three people to sit. Tables are placed in the center of the classroom with space for free play or group games with a teacher. In order for the children to provide as wide a movement as possible both inside and outside, an exit was made from the front of the classroom facing the garden, and special open areas were created for children.

In the classroom spaces where geometric forms are used extensively, the lively atmosphere in the environment is calmed by using light tones. Laminated parquet is used in Zen, water-based paint on the wall surfaces and MDF panels on the game walls.

\section{Student Work 4}

The student, who started out that circular forms are safer and more peaceful forms for children, generally designed the wall surfaces as curvilinear. However, the circular forms do not continue when the spaces are entered (Picture 5).

Research Article - This article was checked by iThenticate 


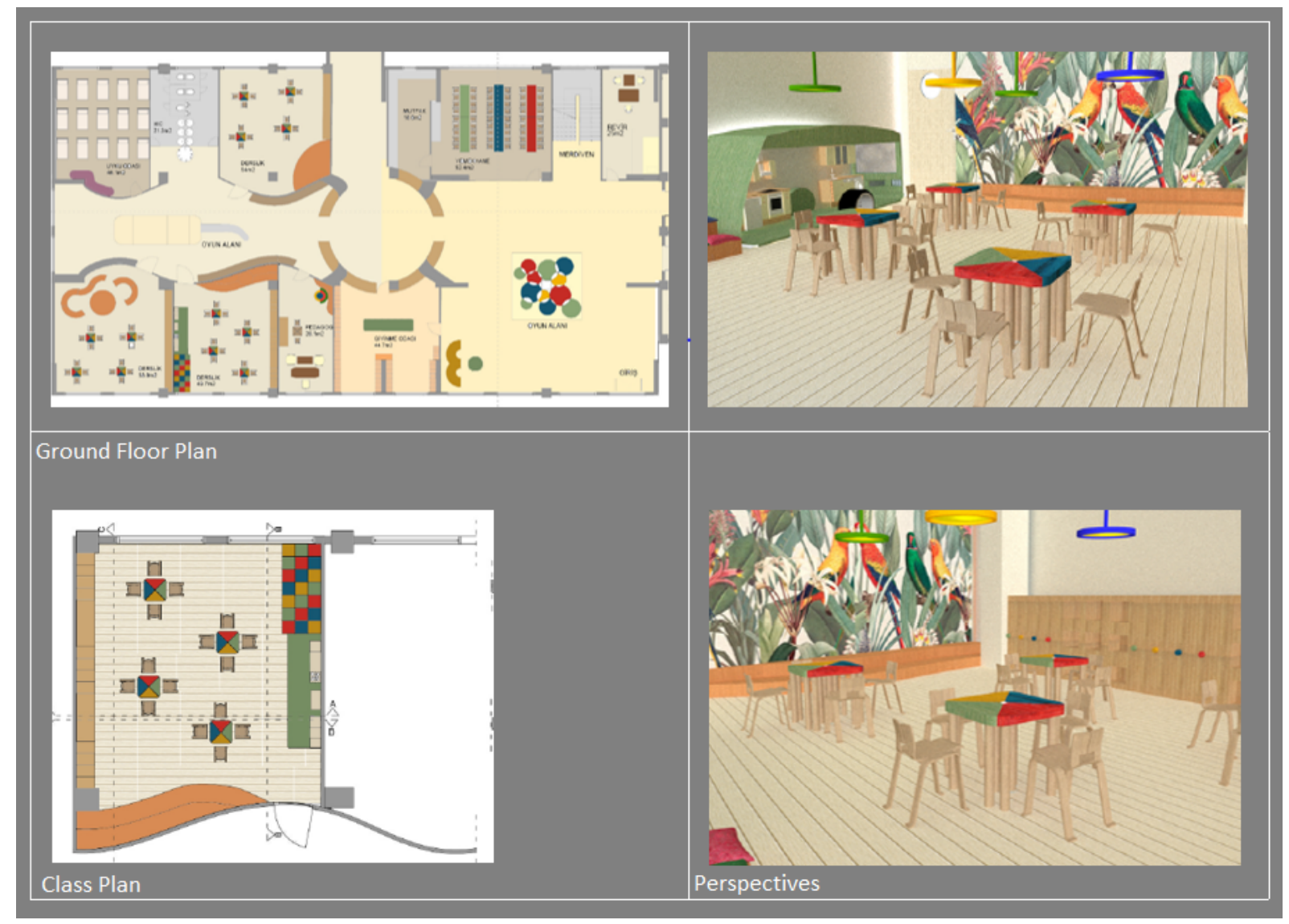

Picture 5. Student drawings and models

In this study, the student designed classes with 12 children. The main purpose of classroom designs is to provide playgrounds that will provide different life experiences to children by analyzing space within the space. Several children can play together in the caravan-like space designed in the classroom. In addition, by making the surfaces in a curvilinear form, it was aimed to convey a fun and mysterious rhythm to the children. With the differences in elevation created in the classrooms, areas for story reading time were defined. 12 tables were arranged in the classrooms where each child can sit individually but can be combined and allow them to do group work. Units for children's personal belongings are designed as open shelf systems and cabinets. He did not prefer to establish a connection between the classroom and the garden in student design. Laminated parquet was used on the floor, themed wallpapers and water-based paint were used on the walls.

\section{Student Work 5}

The student, who started out with the thought that the child who is in constant interaction with his environment is on the move and needs plenty of space, has tried to create wide spaces from the entrance of the building (Picture 6).

Research Article - This article was checked by iThenticate 


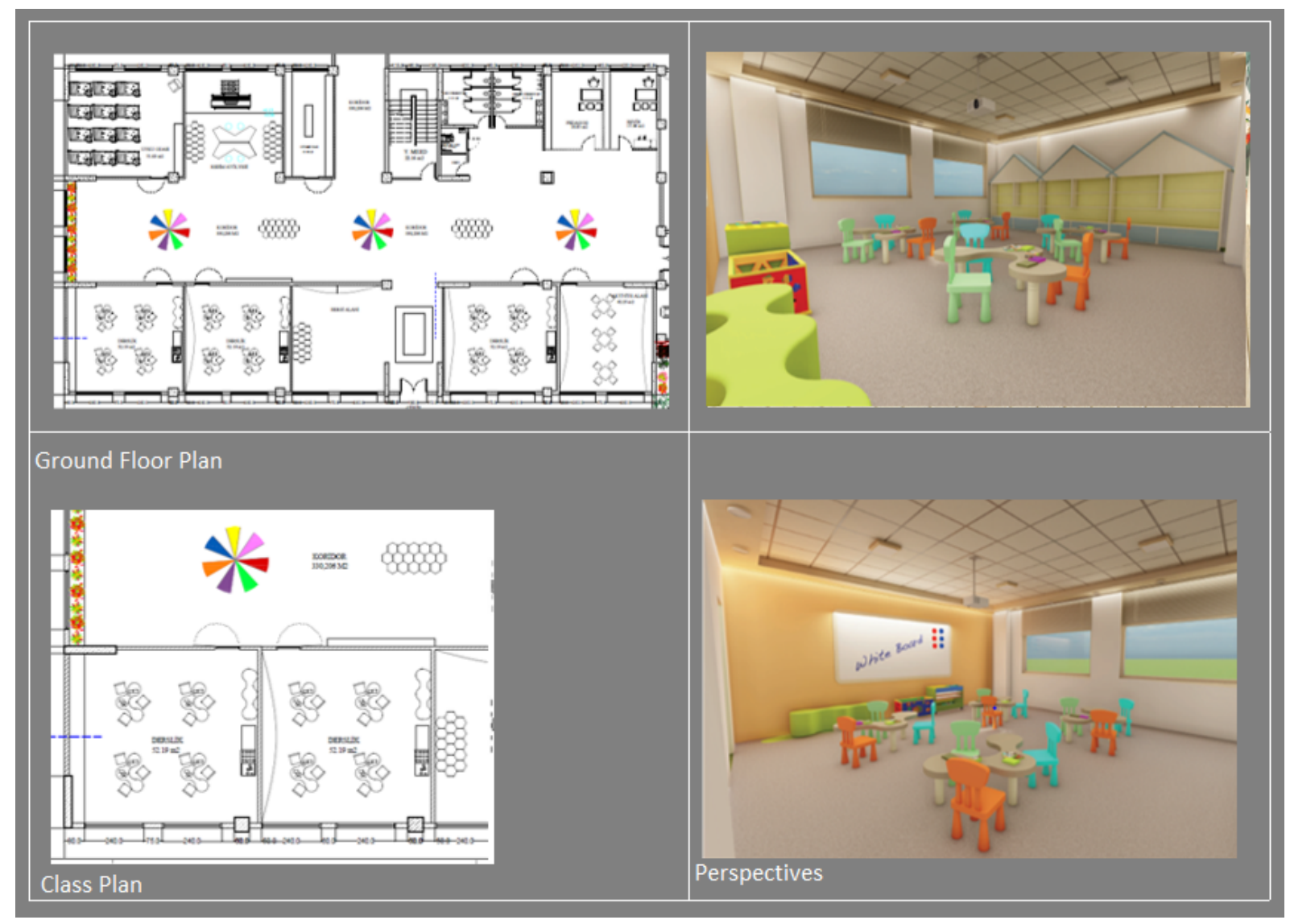

Picture 6. Student drawings and models

In this study, the student designed classes with 12 children. The main purpose of the design is to allow children to move within safe limits. 4 desks were used in the classrooms for three people to sit. Tables are placed in the center of the classroom with space for free play or group games with a teacher. The units for children's personal belongings are designed as open and closed shelving systems. He did not prefer to establish a connection between the classroom and the garden in student design. Antibacterial PVC coating is used on the floor and water-based paint is used on the walls.

\section{CONCLUSION}

Indoor spaces in kindergartens are areas where children come into direct contact. Children start to explore the environment only when they feel comfortable in the place, they are in. For this reason, interior spaces should be designed carefully and correctly. The use of bright and clear colors, unusual shapes, different materials and surface textures are the main factors in attracting the attention of children. It is also very important to design all the items in the space in accordance with the size of the children, to create various niches or activity pockets to make them feel at home as in their own room. No artificial lighting can meet the physical and mental atmosphere created by natural light in educational spaces as in all interior spaces. For this reason, it would be appropriate to make wide openings and even design spaces in direct contact with the garden in the ground floor spaces. Each of the students, who produced projects by making changes on non-bearing walls and stairs, without touching the shell and structural structure of the building, created different designs with colors, forms and textures. Within the scope of this study, the classroom spaces of the student projects were examined, the items they used while designing the classrooms and the points they paid attention to were revealed (Table 1).

Research Article - This article was checked by iThenticate

Copyright (C) The Turkish Online Journal of Design, Art and Communication 
Table 1. Items used in classroom design

\begin{tabular}{|l|l|l|l|l|l|}
\hline & Student 1 & Student 2 & Student 3 & Student 4 & Student 5 \\
\hline $\begin{array}{l}\text { Direct connection points from the } \\
\text { classrooms to the garden }\end{array}$ & & & & & \\
\hline $\begin{array}{l}\text { Functional tables (can be combined and } \\
\text { separated) }\end{array}$ & & & & & \\
\hline $\begin{array}{l}\text { Spaces designed for different life } \\
\text { experiences in classrooms (activity } \\
\text { pockets) }\end{array}$ & & & & & \\
\hline $\begin{array}{l}\text { Level difference } \\
\text { Large spaces for activity and play }\end{array}$ & & & & & \\
\hline Playing areas on wall surfaces & & & & & \\
\hline $\begin{array}{l}\text { Sitting areas on wall surfaces (integrated } \\
\text { with wall units) }\end{array}$ & & & & & \\
\hline
\end{tabular}

As can be seen in the table, three out of five students established a direct connection between the classroom and the garden. Other students made an exit to the garden from the indoor playground or from the school entrance door. Tables in classrooms are the equipment that covers the largest area. However, as is known, it is recommended to have wide openings for activity. For this reason, it is important to design functional tables. Three of the students used tables that can be combined and separated during group activities, while two used tables in organic form and that cannot be combined. Only one of the five students designed spaces that offer different life experiences for children by setting up spaces within the classroom. All students left enough space for the activity area. However, 2 students created a special area for activities such as reading fairy tales and watching didactic movies due to the elevation differences they created in the classroom. Only 1 student considered the wall surfaces as a playground. Only one surface in the space was furnished with wooden puzzles that he could create different forms by using the pull-and-paste method. All students used open and closed shelving systems on the wall surfaces for storage, and two students designed a seating area between these shelves. All of the projects aimed to get the daylight inside at the maximum level. For this reason, the classes are especially placed at the front. In fact, in three of the 5 projects, the corridor was provided with daylight. Students used colors effectively in line with the concept they developed. All of the materials were chosen in a way that would not adversely affect children's health, and all forms were designed in a way that children would not be harmed.

It is known that converting a classroom into a pre-school classroom in an elementary school building is a widely used method to establish pre-school education facilities, but this strategy is not valid (Dudek, 2000). It is clear that this method, which is applied without considering the needs of the children, will have negative effects on the development of children.

If we look at the past years, it is seen that the help of an interior designer was not used much in children's spaces. However, with the realization that children are physically and mentally different from adults and

Research Article - This article was checked by iThenticate 
that they should have special spaces for them, and as a matter of fact, the importance given to children has increased, and the importance given to children's spaces has increased. By giving Kindergarten Design to the students within the scope of the Design Studio, the awareness of young designers was increased and they were provided with the experience of space design according to the ergonomic features of different age groups.

According to Clegg and Billington, when children experience a school obviously designed with their needs in mind, they notice it and demonstrate a more natural disposition towards respectful behaviour and a willingness to contribute to the classroom community (Dudek, 2005). As can be understood from the findings obtained, each student has succeeded in designing ideal spaces for them by touching a different point about the child. Aiming to make space designs that will positively affect the child's perception of space and cognitive development, the students designed the furniture and spaces in accordance with the characteristics of the children in an anthropometric perspective. It is thought that future generations, who are and will be educated in the spaces designed in this way, will exhibit positive behaviors in all aspects.

\section{REFERENCES}

Akyüz, Y. (1996). Anaokullarının Türkiye'deki Kuruluş ve Gelişim Tarihçesi. Milli Eğitim Dergisi, 132, 11-17.

Campbell, H. (2013). Landscape and Child Development, Evergreen, Toronto.

Deretarla Gül, E. (2008). Meşrutiyet’ten Günümüze Okul Öncesi Eğitim. Ç.Ü. Sosyal Bilimler Enstitüsü Dergisi, 17 (1), 269-278.

Dudek, M. (2000). Kindergarten Architecture, Space for the Imagination, Spon Press.

Dudek, M. (2005). Children's Spaces, Architectural Press.

Gür, Ş., Zorlu, T. (2002). Çocuk Mekanları, Yapı-Endüstri Merkezi Yayınları, İstanbul.

MEB (2013). T.C. Millî Eğitim Bakanlığı Temel Eğitim Genel Müdürlüğü Okul Öncesi Eğitim

Program1, Ankara. http://tegm.meb.gov.tr/dosya/okuloncesi/ooproram.pdf Erişim tarihi 20.02.18.

Mohidin, H.H., Ismail, A. S., Ramli, H. B. (2015). Effectiveness of Kindergarten Design in Malaysia. Procedia - Social and Behavioral Sciences 202 (2015) 47 - 57.

Şahin, B. E., Türkün Dostoğulu, N. (2012). The Importance of Preschoolers' Experience in Kindergarten Design. (29:1) 301-320. DOI: 10.4305/METU.JFA.2012.1.17.

\section{ELECTRONIC RESOURCES}

URL-1

http://ozelokullardernegi.org.tr/Mevzuat/OKUL $\% 20 \% \mathrm{C} 3 \% 96 \mathrm{NCES} \% \mathrm{C} 4 \% \mathrm{~B} 0 \% 20 \mathrm{E} \% \mathrm{C} 4 \% 9 \mathrm{E} \% \mathrm{C} 4 \%$

B0T\%C4\%B0M\%20KURUMLARI\%20Y\%C3\%96NETMEL\%C4\%B0\%C4\%9E\%C4\%B0.pdf

(Access Date: 11.04.2021)

URL-2 https://data.tuik.gov.tr/Search/Search?text=\%C3\%A7ocuk (Access Date: 11.04.2021)

Research Article - This article was checked by iThenticate 